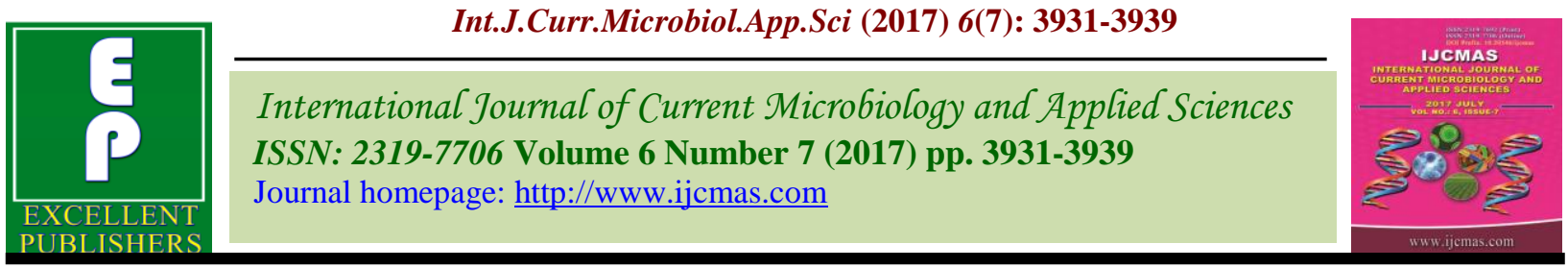

Original Research Article

https://doi.org/10.20546/ijcmas.2017.607.405

\title{
Technology Dissemination and Impact of KVK Activities in the District of Ramanagara, India
}

\author{
K.H. Nagaraj ${ }^{1}$, S. Kamala Bai ${ }^{2}$ and Lata R. Kulkarni ${ }^{3}$ \\ KVK, Ramanagara, India \\ *Corresponding author
}

\begin{abstract}
A B S T R A C T
An attempt was made to analyze the impact and up-scaling of technologies disseminated by KVK, Ramanagara at both micro (IFSD initiative) and macro level (district Level). For the purpose of the study, primary data available at data bank of KVK along with the supplementary data from the farmers was used. To create awareness about various technologies to farmers at macro level, KVK adopted cognizance, approach where in 271 group discussion meetings were conducted covering 5069 farmers. A great majority of the farmers (89\%) could adopt the jasmine budworm management practices demonstrated by KVK resulting in increased income of Jasmine growers to Rs.87654/- per ha from Rs.46874/-. The analysis of query type seeking information revealed that 16097 farmers sought information through telephone calls apart from agriculture short message service (4700 farmers) KVK, Ramanagara implemented IFSD project covering 2871 stakeholders from 2011-2014. The effect of technology induction to strengthen enterprises of stakeholders was valuable. Induction of fruit fly traps in mango, reduced the fruit fly incidence by $52 \%$ resulting in additional increase in income of Rs.9400/- per ha of mango. The issues of way forward for the KVK and the entire stakeholders involved are to upscale the interventions in terms of technologies considering vertical and horizontal spread. There is a need to build conditions for enhanced crop productivity in the present climate change scenario.
\end{abstract}

\section{Introduction}

Ramanagara District is one among the 30 districts of Karnataka state. It is predominantly a dry farming district which lies in geographic position of North latitude between $12^{\circ} 33^{\prime}$ to $12^{\circ} 58^{\prime}$ and East longitude $77^{\circ} 13$ to $77^{\circ} 25^{\prime}$. The district falls under Zone 5 Agro- Climatic zones of Karnataka comprising four taluks viz., Ramanagara, Magadi, Chanpatna and Kanakapura with 18 hoblies. Krishi Vigyan Kendra's (KVK) in the district of Ramanagara serves as a storehouse of scientific knowledge that is useful to farmers in all angles of their livelihood.
Increasing population pressure and industrialization have already squeezed out limited resources leading to decreased productivity of crops. In general, one per cent increase in GDP leads to 0.052 decrease in the percentage of people employed in agriculture (Anonymous, 2013). The surreptitious of success in agriculture is associated closely to wide scale adoption of improved technologies by the farmers. KVK has disseminated various technologies since its inception during 2010. The main role of KVKs in the context of agricultural extension is more of 
'Informative than emancipatory extension and thus performs the duty of front line extension. Through KVKs, technologies are extended to farming community in the form of on-farm testing (OFT) to identify location-specific technologies under different farming systems. Frontline demonstration (FLD) is conducted to display the production potential of newly released production technologies in farmer's field. A number of extension educational activities including training to farmers and extension workers are carried out by KVK. With the support of University of Agricultural Sciences, Bangalore, KVK also initiated 'Integrated Farming System for Sustainable Livelihood' (IFSD Project) in 48 villages of Magadi taluk covering 2871 stakeholders from 2011-12 to 2014-15. In the milieu, the study was conducted to analyze the technology induction, dissemination approaches and its impact at micro level (considering IFSD) and macro level (district level).

\section{Materials and Methods}

For the purpose of the study at District level, primary data available at data bank of KVK, Ramanagara was used to begin with and the supplementary data was collected from the farmers who participated in the activities of KVK. 110 farmers who actively participated in $\mathrm{KVK}$ activities across the district and in turn contacted the kendra for various information were selected purposefully for the study to analyze the impact of KVK activities at macro level. The database of the list of beneficiary farmers who either visited KVK or obtained information through telephone and any other means is being maintained at KVK. Further, for the purpose of the study under micro level situation (IFSD), the secondary data available at data bank of KVK was also used as a starting point. With the aid of resulting secondary data, additional information from the beneficiaries of the project was also collected to analyze the impact of technological interventions of KVK under IFSD. Three Grama Panchayat's viz., Kalya, Kaleri and Hosapalya where IFS was initiated were selected for the study. From each Grama Panchayat, four villages were selected. Again, from each village 10 farmers where IFS was initiated were selected for the study. Thus the sample size for the study under micro level was 120 farmers from 12 villages of Magadi taluk of Ramanagara District of Karnataka. Thus the overall total sample for the study is 230 farmers (110 at macro and 120 at micro level).

\section{Results and Discussion}

\section{Technology Dissemination Approaches and Impact of Technologies under Macro Level Situation}

KVK bridges the gap between the technologies developed at the research institutions and its adoption at the field level by the farmers through various approaches. The data depicted in Table 1 indicates that, to create awareness about various technologies to farmers, KVK adopted cognizance approach where in 271 group discussion meetings were conducted covering 5069 farmers. The other methods of cognizance approach were news coverage (248 Nos) and extension literature (112 Nos). As a tool of ICT, KVK has implemented Agriculture Short Message Service (ASMS). Till date 403 SMS were sent reaching 4700 farmers. Methodological approach is the main stay of KVK to up-scale technologies to farmers. Frontline demonstrations (112), on-farm testing (36), on-campus and off-campus training programs (355) covering 11894 farmers and 38 field days reaching 2275 farmers were conducted. It is interesting to note the horizontal spread of technologies particularly fodder seed material $(690400$ cuttings) wherein 148 farmers were involved 
in disseminating to 530 other farmers. Similarly 42601 Bhagya variety of drumstick seedlings were utilized by 231 farmers increasing the area under drumstick to 32 ha in the district. KVK, Ramanagara is also preparing mango and banana special and making it available to farmers of the district covering so far 1090 farmers within a span of two years.

The impact of any intervention in the technology is measured in terms of the benefits reaped by the farmers, improvement on socio economic condition and nutrition security. The fact depicted in Table 2 reveals the technologies transferred, received by the farmers and their adoption level including the change in income revealing the impact of technologies disseminated by KVK. In collaboration with Coconut Development Board, KVK has conducted skill oriented capacity building program on coconut climbing and plant protection for 140 youths of the district including women. The technology was well received by the youth wherein $92 \%$ of them adopted the technology ie., they have put in to use the skill learnt for climbing their own trees. Some of them are working as a task force for climbing coconut on chargeable basis. One successful entrepreneur Mr. Naveen of Odakehosahally village of Channapattana Taluk of Ramanagara District is earning on an average of Rs.18000/- per month as coconut service provider after getting trained by KVK during 2013. Mr. Naveen is also serving as a master trainer for coconut climbing during the training programs conducted by KVK. The average income earned by the trained youth has increased to Rs. 15,000/- from Rs.3300/which they were earlier earning by working as labour.

A great majority of the farmers $(89 \%)$ could adopt the jasmine budworm management practices demonstrated by KVK resulting in increased income of Jasmine growers to Rs.87654/- per ha from Rs.46874/- per ha. Several improved varieties of ragi viz., MR-1, MR-6, KMR-301, KMR-204 ML-365, GPU66, GPU-24 and GPU-66 were demonstrated to 2825 farmers out of which, $37 \%$ of farmers could adopt new improved varieties in the later seasons. Adopting scientific management practices in silkworm rearing increased income from Rs.12,000 to Rs. 17,000 for 100 DFLs. Under crop production activity, weeding incurs huge cost of cultivation. Availability of labour is a major constrain. To overcome the problem of labour constraint, reduce the drudgery and cost of weeding, KVK introduced cycle weeder which is a handy implement to remove weeds. The introduction of cycle weeder reduced the cost of cultivation in weeding by $77 \%$ over manual weeding and increased the income from Rs. 1250 to Rs.5600 / ha. Out of 320 farmers who have received the cycle weeder technology, $26 \%$ have adopted the same. To improve the livelihood of the farmwomen, value addition for commonly grown crops like Ragi and Jack fruit was demonstrated. Earlier the produce was sold as raw ragi and jack as a whole fruit. Later after the training on value added products viz., ragi malt, ragi papad, jack chips, jack fruit jam, the income increased drastically form Rs. 3 to Rs. 37 / kg of ragi and Rs.20 to Rs.84 per kg of jack bulbs.

Ragi is the major field crop in the district. Situation analysis revealed that a great majority of the stake holders lacked knowledge about improved varieties which contributes for higher productivity (Amithya et all. 2013). In order to increase the yield and productivity, old varieties were replaced by improved varieties that increased farmers annual income from Rs.18750/- to Rs.23450/per ha. Livestock rearing is strongly integrated with various farming systems. Since crop residues form the major portion of 
animal feed, the integration of livestock rearing in farming systems is common (Ghosh et al., 2014). It is acceptable to see that $55 \%$ of farmers have adopted the technology in terms of cultivating improved fodder varieties like Co-3, Co-4, DHN-6 and COFS-29. (Table 2).

Mango is one of the major dry land fruit crops cultivated vastly in the district and majority of the farmers outsource the mango orchards to the traders for harvesting and sale of the crop. KVK interfered with few interested mango growers and motivated those to take up ripening, branding and marketing of the mango at farm level and sell mangoes directly to consumers under the brand name of 'Ram Gold'. This resulted in drastic increases in the income of farmers from Rs.47500 / ha /year to Rs.2,65,500 / ha / year at initial phase of interventions (Table 2). With the horizontal spread of technology to the FLD participated and non- participated farmers, the income from direct marketing over on farm contract increased by $360 \%$ and the additional income obtained from APMC market over on Farm Contract varied from 183 to $200 \%$ (Table 3). Similar findings were reported by Shubha Ranjitha (2012). The cases of four farmers who actively involved in direct marketing and earning more income are depicted in table 3.

Extension activities such as frontline demonstrations, field days and training programs were carried out by KVK over the years to create awareness about the importance of different technologies introduced by KVK since inception viz., Improved ragi, redgram, field bean, horse gram, minor millets and groundnut varieties, Coconut climbing, mango ripening and marketing, Jasmine budworm management, Improved sericulture practices, Cycle weeder, Value addition in ragi and jack and Improved fodder production. In order to disseminate technologies to large number of farmers, several extension activities were conducted with a view to up-scale the introduced technologies. Since 2010, information on different technologies was provided to 16097 farmers over telephone apart from 5318 farmers visiting KVK to seek information. 8238 farmers mostly youth through offcampus training and 3306 farmers through on-campus training were appraised about various technologies (Table 4). It is interesting to note that, recently farmers have sought information through WhatsApp particularly the pest and disease symptoms of plants from the specialists of KVK. This is a new ICT tool through which farmers are seeking information from KVK. Overall, 45378 farmers have sought information related to various agricultural technologies from KVK.

\section{Effect of technology induction in micro- level situation under IFSD}

Combination of different enterprise within the farming system remains the backbone of agriculture in sustaining the livelihoods of majority of Indian farmers. The role and nature of involvement of component enterprises and mechanism to encourage greater use of profitable enterprise combinations to produce more food from shrinking land resources, would assume greater importance for spearheading the agricultural growth (Swaminathan, 2005). Efforts were made to strengthen different enterprises of stakeholders by inducting critical inputs that would gain additional income to farmers through increased productivity. The particulars depicted in Table 5 revealed that chawki rearing trays were not known earlier to farmers leading to death of worms and ultimately low productivity. The induction of chawki rearing trays increased the cocoon yield by $20 \%$ resulting in additional income of Rs.4500/per 100 DFLs in seed area. Area specific 
mineral mixture and improved cattle feed was inducted to 389 dairy farmers as a result of which the milk production increased by $8 \%$ obtaining additional income of Rs.2310 per lactation per animal. As a nutritional supplement, area specific sheep mineral mixture was also introduced to 2137 farmers that resulted in $114 \%$ increase in body weight of the sheep by the end of three years generating an average income of Rs.8800/per sheep.
Due to induction of fruit fly traps in mango, the fruit fly incidence reduced by $52 \%$ resulting in additional increase in income of Rs.9400/- per ha of mango. The wilt incidence in redgram could be controlled to the extent of $75 \%$ through introduction of trichoderma subsequent to which Rs.4300/additional income was obtained per ha. Improved fodder crops viz., $\mathrm{CO}-3$ and $\mathrm{CO}-4$ were introduced to 1509 farmers resulting in $6.6 \%$ increase in milk yield.

Table.1 Dissemination Approaches Adopted by KVK to Up-Scale Technologies since Inception

\begin{tabular}{|c|c|c|c|}
\hline Approach & Methods & No/Programs & $\begin{array}{l}\text { Number of farmers } \\
\text { reached }\end{array}$ \\
\hline \multirow{5}{*}{$\begin{array}{l}\text { Cognizance } \\
\text { Approach }\end{array}$} & Focused Group Discussions & 271 & 5069 \\
\hline & Extension literature & 112 & - \\
\hline & TV Programs & 21 & - \\
\hline & Radio Programs & 29 & - \\
\hline & News Coverage & 248 & - \\
\hline \multirow{9}{*}{$\begin{array}{l}\text { Methodological } \\
\text { Approach }\end{array}$} & Front line Demonstrations conducted & 112 & 1335 \\
\hline & On-farm testing & 36 & 215 \\
\hline & Field Days conducted & 38 & 2275 \\
\hline & On-Campus training programs to farmers & 103 & 3043 \\
\hline & Off-Campus training programs to farmers & 252 & 8851 \\
\hline & Facilitators training & 28 & 976 \\
\hline & Stake holder Sensitization programs & 12 & 155 \\
\hline & ICT application (ASMS) & 403 & 4700 \\
\hline & Method Demonstrations at KVK & 407 & 11994 \\
\hline \multirow{13}{*}{$\begin{array}{l}\text { Technology } \\
\text { dissemination }\end{array}$} & \multicolumn{3}{|l|}{ Seed material produced, sold and distributed } \\
\hline & Ragi (MR-6, GPU-66) & $11262 \mathrm{kgs}$ & \multirow{9}{*}{3497} \\
\hline & Redgram (BRG-1, BRG-2 and BRG-5) & $1420 \mathrm{kgs}$ & \\
\hline & Cowpea (C-152, IT-38956) & $1537 \mathrm{kgs}$ & \\
\hline & Horsegram (PHG-9) & $2881 \mathrm{kgs}$ & \\
\hline & Field bean (HA4) & $259 \mathrm{kgs}$ & \\
\hline & Foxtail (HMT 100-1) & $603 \mathrm{kgs}$ & \\
\hline & Sunhemp (Local) & $2213 \mathrm{kgs}$ & \\
\hline & Groundnut (GKVK-5) & $140 \mathrm{kgs}$ & \\
\hline & Fodder (CO3, CO4, DHN-6, COFS29) & $\begin{array}{l}690400 \\
\text { cuttings }\end{array}$ & \\
\hline & $\begin{array}{l}\text { Farmer-Farmer dissemination of fodder } \\
\text { cuttings }\end{array}$ & 148 & 530 \\
\hline & Drumstick Seedlings (Bhagya) & 42601 & 231 \\
\hline & Mango and Banana Special & 4360 & 1090 \\
\hline
\end{tabular}


Table.2 Impact of different technologies disseminated by KVK since inception

\begin{tabular}{|c|l|c|c|c|c|}
\hline Sl. & Name of the technology/ & Technology & \multirow{2}{*}{$\begin{array}{c}\% \\
\text { Receivers }\end{array}$} & \multicolumn{2}{|c|}{ Change in income $($ Rs. $)$} \\
\cline { 5 - 6 } No & skill transferred & Before & After \\
\hline 1 & Coconut climber & 140 & 92.0 & 3300 & 15000 \\
\hline 2 & $\begin{array}{l}\text { Mango ripening, } \\
\text { branding and marketing }\end{array}$ & 836 & 46.0 & $\begin{array}{c}47500 \\
/ \text { ha }\end{array}$ & $\begin{array}{c}262500 \\
/ \text { ha }\end{array}$ \\
\hline 3 & $\begin{array}{l}\text { Jasmine budworm } \\
\text { management }\end{array}$ & 25 & 89.0 & 46874 & 87654 \\
\hline 4 & $\begin{array}{l}\text { Improved silkworm } \\
\text { rearing practices }\end{array}$ & 269 & 33.0 & $\begin{array}{c}12,000 / 100 \\
\text { DFLs }\end{array}$ & $17,000 / 100$ DFLs \\
\hline 5 & $\begin{array}{l}\text { Cycle weeder (cost of } \\
\text { weeding charges per ha) }\end{array}$ & 320 & 26 & 5600 & 1250 \\
\hline 6 & $\begin{array}{l}\text { Value addition in Ragi } \\
\text { (per Kg of ragi) }\end{array}$ & 47 & 5.0 & 3 & 37 \\
\hline 7 & $\begin{array}{l}\text { Value addition in Jack } \\
\text { (per Kg of bulbs) }\end{array}$ & 47 & 3.0 & 20 & 84 \\
\hline 8 & Improved Ragi Varieties & 2825 & 37.0 & $18750 / \mathrm{ha}$ & $23450 / \mathrm{ha}$ \\
\hline 9 & $\begin{array}{l}\text { Improved fodder } \\
\text { production }\end{array}$ & 1224 & 55.0 & $\begin{array}{c}18400 \\
\text { /animal/yr }\end{array}$ & $\begin{array}{c}23500 \\
\text { /animal/yr }\end{array}$ \\
\hline
\end{tabular}

Table.3 Impact of direct marketing on the income of trained mango growers

\begin{tabular}{|c|c|c|c|c|c|c|}
\hline \multirow[t]{2}{*}{ Farmer } & \multirow{2}{*}{$\begin{array}{c}\text { Total } \\
\text { yield }(t)\end{array}$} & \multicolumn{3}{|c|}{ Income (Rs.) } & \multirow{2}{*}{$\begin{array}{l}\text { Income from } \\
\text { direct } \\
\text { marketing } \\
\text { over on } \\
\text { farm } \\
\text { contract (\%) }\end{array}$} & \multirow{2}{*}{$\begin{array}{l}\text { Addl. } \\
\text { Income from } \\
\text { APMC } \\
\text { market over } \\
\text { on farm } \\
\text { contract }(\%)\end{array}$} \\
\hline & & $\begin{array}{l}\text { On farm } \\
\text { contract }\end{array}$ & $\begin{array}{l}\text { Sale at } \\
\text { APMC }\end{array}$ & $\begin{array}{c}\text { Direct } \\
\text { marketing }\end{array}$ & & \\
\hline Vasu & 7.0 & 87500 & 175000 & 630000 & 360 & 200.00 \\
\hline Narasihamurthy & 11.0 & 150000 & 275000 & 880000 & 320 & 183.33 \\
\hline Varadaraju & 5.0 & 65000 & 125000 & 400000 & 320 & 192.30 \\
\hline Shivaramaiah & 8.00 & 112000 & 200000 & 720000 & 360 & 178.57 \\
\hline Total & 7.75 & 103625 & 193750 & 657500 & 340 & 188.55 \\
\hline
\end{tabular}


Table.4 Query type-wise distribution of farmer seeking information from KVK since inception

\begin{tabular}{|c|l|c|}
\hline $\begin{array}{c}\text { Sl. } \\
\text { No }\end{array}$ & \multicolumn{1}{|c|}{ Query type } & $\begin{array}{c}\text { No. of farmers } \\
\text { (2010-11 to 2016-17) }\end{array}$ \\
\hline 1 & Telephone Calls & 16097 \\
\hline 2 & $\begin{array}{l}\text { Farmers personal visit to KVK (since 2010) } \\
\text { for advisory services }\end{array}$ & 5318 \\
\hline 3 & Through Off-campus training programs & 8238 \\
\hline 4 & Through On-Campus training programs & 3306 \\
\hline 5 & Scientists visit to farmers field & 3787 \\
\hline 6 & Diagnostic field visits & 1045 \\
\hline 7 & Agriculture short message service & 4700 \\
\hline 8 & Farm advisory & 2633 \\
\hline 9 & Whats App (since 2014) & 254 \\
\hline & \multicolumn{2}{c}{ Total } \\
\hline
\end{tabular}

Table.5 Effect of technology induction for strengthening different enterprises under IFSD project

\begin{tabular}{|l|c|l|c|c|c|c|}
\hline \multirow{2}{*}{$\begin{array}{l}\text { Technological } \\
\text { Intervention }\end{array}$} & $\begin{array}{c}\text { No. of } \\
\text { farmers } \\
\text { covered }\end{array}$ & Parameter / Unit & $\begin{array}{l}\text { Bench } \\
\text { Mark }\end{array}$ & Demo & $\begin{array}{c}\text { \% increase } \\
\text { or decrease }\end{array}$ & $\begin{array}{c}\text { Additional } \\
\text { income } \\
\text { (Rs. /ha })\end{array}$ \\
\hline $\begin{array}{l}\text { Chawki rearing } \\
\text { trays }\end{array}$ & 150 & $\begin{array}{l}\text { Cocoon yield per } \\
\text { 100 DFLs (Kg) }\end{array}$ & 45 & 54 & 20 & 4500 \\
\hline $\begin{array}{l}\text { Area specific } \\
\text { mineral mixture } \\
\text { and cattle feed }\end{array}$ & 389 & $\begin{array}{l}\text { Milk yield } \\
\text { (lts/day/animal) }\end{array}$ & 6.5 & 7.00 & 8 & 2310 \\
\hline $\begin{array}{l}\text { Sheep mineral } \\
\text { mixture (area } \\
\text { specific) }\end{array}$ & 2137 & $\begin{array}{l}\text { Body Weight } \\
\text { (Kg) }\end{array}$ & 7 & 22 & 114 & 8800 \\
\hline $\begin{array}{l}\text { Mango fruit fly } \\
\text { traps }\end{array}$ & 117 & $\begin{array}{l}\text { Pest Infestation } \\
(\%)\end{array}$ & 85 & 33 & -52 & 9400 \\
\hline $\begin{array}{l}\text { Trichoderma } \\
\text { viride }\end{array}$ & 560 & $\begin{array}{l}\text { Wilt incidence } \\
(\%)\end{array}$ & 48 & 12 & -75 & 4300 \\
\hline $\begin{array}{l}\text { Pruning } \\
\text { secateurs }\end{array}$ & 96 & $\begin{array}{l}\text { labour charges } \\
\text { for pruning per } \\
\text { ha (Rs) }\end{array}$ & 3000 & 300 & 90 & \\
\hline $\begin{array}{l}\text { Fodder: C0-3, } \\
\text { Co-4 and DHN- } \\
6\end{array}$ & 1509 & $\begin{array}{l}\text { Milk yield } \\
\text { (lts/day/animal) }\end{array}$ & 7.25 & 7.75 & 6.6 & 2310 \\
\hline
\end{tabular}


Table.6 Extension activities conducted to create awareness and up-scale the technologies under IFSD

\begin{tabular}{|c|c|c|c|c|c|c|c|c|}
\hline \multirow[t]{2}{*}{ Activity } & \multicolumn{2}{|c|}{$2012-13$} & \multicolumn{2}{|c|}{$2013-14$} & \multicolumn{2}{|c|}{$2014-15$} & \multicolumn{2}{|c|}{ Total } \\
\hline & $\begin{array}{c}\text { No of } \\
\text { Progra } \\
m s\end{array}$ & $\begin{array}{c}\text { No. of } \\
\text { farmers }\end{array}$ & $\begin{array}{c}\text { No of } \\
\text { Progra } \\
m s\end{array}$ & $\begin{array}{c}\text { No. of } \\
\text { farmers }\end{array}$ & $\begin{array}{c}\text { No of } \\
\text { Progra } \\
m s\end{array}$ & $\begin{array}{c}\text { No. of } \\
\text { farmers }\end{array}$ & $\begin{array}{c}\text { No of } \\
\text { Progra } \\
m s\end{array}$ & $\begin{array}{c}\text { No. of } \\
\text { farmers }\end{array}$ \\
\hline $\begin{array}{l}\text { Animal Health } \\
\text { Camps }\end{array}$ & 18 & 2089 & - & - & - & - & & \\
\hline Follow-up visits & 23 & 880 & 16 & 560 & 18 & 628 & & \\
\hline $\begin{array}{l}\text { Group } \\
\text { Discussions }\end{array}$ & 8 & 260 & 12 & 352 & 14 & 364 & & \\
\hline $\begin{array}{l}\text { Capacity } \\
\text { Building } \\
\text { (Training } \\
\text { programs / } \\
\text { Demonstrations } \\
\end{array}$ & 12 & 477 & 8 & 200 & 6 & 164 & 155 & 6665 \\
\hline $\begin{array}{l}\text { Soil Sampling } \\
\text { Demo }\end{array}$ & 15 & 417 & - & - & - & - & & \\
\hline Exposure visits & - & - & 3 & 175 & 2 & 99 & & \\
\hline Total & 76 & 4123 & 39 & 1287 & 40 & 1255 & & \\
\hline
\end{tabular}

In order to create awareness and up-scale the technologies among IFSD stakeholders, several extension activities were conducted. A close look at the Table 6 indicates that as many as 18 animal health camps were conducted in collaboration with the department of animal husbandry covering 2089 farmers. This was concentrated during 2012-13 since sheep's were inducted to stake holders during the period. Group discussion meetings (34) were conducted covering 976 farmers in order to discuss problems of farmers and elicit solutions for the same. Training programs and demonstrations (26) were conducted to build the capacity of 841 farmers. Soil sampling technique demonstration (15) and five exposure visits were also conducted. Overall 155 programs as part of extension activities covering 6665 farmers were conducted to up-scale the technologies so introduced at micro level situation under IFSD.

In conclusion, induction and dissemination of various technologies on crop production and animal husbandry activities have impacted on the yield and income of the farmers. It is proposed in general to educate farmers about the importance of IFS through various approaches. The issues of way forward for the $\mathrm{KVK}$ and the entire stakeholders involved are to up-scale the interventions in terms of technologies considering vertical and horizontal spread. There is a need to build conditions for enhanced crop productivity in the present climate change scenario (Reena Kandwal, 2013). KVK would put every efforts to improve the farming situation of farmers by working in cluster villages and their by involving line departments to further up-scale the technologies.

\section{References}

Amithya Rakshit Pal, S., Rai, S.A., Rai, Bhowmick, M.K. and Singh, H.B., 2013. Micronutrient seed Priming: a potential tool in integrated Nutrient Management, SATSA Mukhpatra Annual Technical Issue, 17: 77-89. 
Anonymous. 2013. http://invested development.com/blog/2013/06/theimpact-of-technology- in-agriculture/

Ghosh, P.K., Sunil Kumar and Ram, S.N. 2014. Opportunities for forage production, Indian Farming, 63(11): 47 50.

Reena Kandwal. 2013. Role of KVKs in the Climate Change Scenario, Indian
Farming, 63(8): 3-6.

Shubha Ranjitha. 2012. Economic Analysis of Production and Marketing of Jaggery in Mandya District of Karnataka. Mysore J. Agric. Sci., 46(4): 942.

Swaminathan, M.S. 2005. Sci. India's Agri. Future, The Hindu (Delhi Edn.), October, 17, pp10.

\section{How to cite this article:}

Nagaraj, K.H., S. Kamala Bai and Lata R. Kulkarni. 2017. Technology Dissemination and Impact of KVK Activities in the District of Ramanagara. Int.J.Curr.Microbiol.App.Sci. 6(7): 3931-3939. doi: https://doi.org/10.20546/ijcmas.2017.607.405 